\title{
Predicting effective aquaculture in subtropical waters: A dynamic energy budget model for the green lipped mussel, Perna viridis
}

\author{
Martin C.F. Cheng ${ }^{\mathrm{a}}$, Alicia L.S. Tan ${ }^{\mathrm{a}}$, Alessandro Rinaldi ${ }^{\mathrm{b}}$, Antonio Giacoletti ${ }^{\mathrm{b}}$, Gianluca Sarà ${ }^{\mathrm{b}}$, \\ Gray A. Williams, ${ }^{\mathrm{a}, *}$
}

${ }^{a}$ The Swire Institute of Marine Science and School of Biological Sciences, The University of Hong Kong, Pokfulam Road, Hong Kong, China

${ }^{\mathrm{b}}$ Department of Earth and Marine Sciences, University of Palermo, Palermo, Italy

\section{A R T I C L E I N F O}

\section{Keywords:}

DEB mode

Environmental pollution

Perna viridis

Parameterisation

Aquaculture management

\begin{abstract}
A B S T R A C T
The green lipped mussel, Perna viridis, is an important aquaculture species throughout the Indo-Pacific region where production is often impacted by environmental degradation. To predict the impacts and mitigate against environmental problems due to various kinds of anthropogenic pollution, such as heavy metals and eutrophication, on $P$. viridis aquaculture a Dynamic Energy Budget (DEB) model was constructed. By integrating species-specific parameters and regional-specific environmental data the DEB model determined how the life history traits of $P$. viridis respond to changing environmental conditions. Using various levels of basal maintenance costs and food availability to elucidate the energetic costs due to environmental pollution, the DEB model predicted that a $20 \%$ increase in basal maintenance cost due to environmental pollution such as heavy metals will result in a subsequent decrease in both lifetime reproductive output and ultimate body size of $P$. viridis by $\sim 18 \%$ and $\sim 8 \%$, respectively. Increasing food availability can, however, mitigate the energetic constraints due to increased basal maintenance cost. The time to reach commercial size, for example, will be longer by $13 \%$ and $3 \%$ under lower and higher food availability conditions, respectively when there is a $20 \%$ increase in maintenance cost due to environmentally induced stress, which would significantly increase the operational cost of an aquaculture facility. In light of the increased importance of $P$. viridis as an aquaculture species, the $P$. viridis DEB model can, therefore, be used to illustrate the effects of varying environmental conditions on $P$. viridis life history traits which are relevant to the success of aquaculture facilities, and contribute towards better management of this species.
\end{abstract}

\section{Introduction}

Marine bivalves are important both in terms of their ecological roles and increasingly in terms of being aquaculture species (Gutiérrez et al., 2003). Shellfish aquaculture is becoming a more important component of the world's food supply (FAO, 2016), given the high nutrient content of bivalves (Gopalakrishnan and Vijayavel, 2009). The green lipped mussel, Perna viridis, which is widely distributed throughout the IndoPacific region (Sidall, 1980), is among the most important aquaculture species in Southeast Asian countries (Rajagopal et al., 2006) with a 43\% increase $(\sim 650,000 t)$ in production over the past two decades (FAO, 2015). A major concern for the future of this industry in Southeast Asia is the impact of coastal water degradation, as a result of multiple anthropogenic activities at both local and regional scales (Williams et al., 2016; Martinez et al., 2018; Sarà et al., 2018), which impact the viability and hence production of aquaculture species (Handisyde et al.,
2006).

Mussel farming is often operated along coastal areas which are susceptible to anthropogenic pollution such as heavy metals and eutrophication, which impact the commercial production of shellfish resources (Chalermwat et al., 2003; Cheevaporn and Menasveta, 2003; Siah et al., 2003; Islam and Tanaka, 2004; Casas and Bacher, 2006). Given the increasing demand for shellfish production (FAO, 2015), understanding how environmental changes may affect a species' life history (LH) traits such as ultimate size and total egg production is crucial when designing aquaculture management strategies (BéjaouiOmri et al., 2014; Rinaldi et al., 2014). The success of aquaculture practice will be dependent on environmental characteristics which fundamentally affect growth of species, which is characteristically the most important trait to determine profitability of such practices (Sarà et al., 2018). Site selection for optimal environmental conditions for shellfish culture is, therefore, a key step to optimize profit and minimize

\footnotetext{
* Corresponding author

E-mail address: hrsbwga@hku.hk (G.A. Williams).
} 
the environmental impacts brought by the industry (Longdill et al., 2008).

Although the physiology of Perna viridis has been well studied (reviewed by Rajagopal et al., 2006), such information is based on shortterm experiments under specific environmental conditions. In reality, however, organisms live in a multi-dimensional ecological space (sensuHutchinson, 1957), including the complex interactive influences of various environmental factors which can be additive, synergistic or antagonistic (Gunderson et al., 2016; Sarà et al., 2018). It is, therefore, difficult to disentangle the effects of environmental changes on organisms when there is no integration between how multiple environmental factors affect species' functional traits such as physiology (Howard et al., 2013; Todgham and Stillman, 2013), energy acquisition and allocation (Smolders et al., 2005; Sokolova, 2013), all of which are needed to predict consequences to LH traits (e.g., growth and reproduction; Petes et al., 2007, 2008). Physiological studies are generally unable to integrate these effects and, therefore, limit our ability to predict the responses of species to varying environmental conditions.

Dynamic Energy Budget theory (DEB; Kooijman, 2010) has been developed to provide an integrative approach to link basal physiological information with environmental conditions, in a mechanisticbioenergetic framework. In essence, the DEB model captures the processes of energy acquisition and utilization in an organism under varying environmental conditions based on First Principles (Nisbet et al., 2000; Van der Meer, 2006; Filgueira et al., 2011) as applied to a suite of parameters that describe the physiology responses of a species to environmental variation. The DEB model, therefore, integrates the energy allocation strategies adopted by species, and allows subsequent prediction of LH traits (e.g., growth and reproductive potential) in response to changes in environmental variables such as temperature and food density (Van der Meer, 2006; Filgueira et al., 2011; Sarà et al., 2013). As such, by varying environmental parameters, one can estimate performance of a species under differing environmental conditions, which can inform aquaculture management practices.

Here, we first parameterize Perna viridis and then use the mechanistic, predictive power of the DEB model to investigate the effects of changing somatic maintenance costs on the main LH end-points (ultimate size, growth as expressed in time to reach commercial size, reproductive potential etc.) using different scenarios. Such an approach allows us to predict $P$. viridis performance under different aquaculture conditions. Specifically, we investigated how environmental pollution may affect the mussel's energy allocation strategies (by varying the somatic maintenance DEB parameter), and this approach can be used to provide quantitative baseline information when assessing issues dealing with aquaculture management for $P$. viridis by scientists, policy makers and stakeholders.

\section{Materials and methods}

\subsection{Approach and animal collection}

To create the DEB model and then use the model to predict mussel LH traits and production under different scenarios, the study employed two approaches. The first involved collection of eco-physiological parameters, both through a systematic analysis of the current literature (Mangano and Sarà, 2017) and empirically, which are necessary for DEB model parameterization. The second used a modeling approach to simulate the ultimate size, reproductive output and the time to reach commercial size of Perna viridis under varying levels of energetic constraints and trophic conditions as might be experienced in an aquaculture context.

To obtain species-specific parameters required to populate the DEB model Perna viridis were collected between Feb 2014 and Jun 2015 from an aquaculture farm located at Tolo Harbour, Hong Kong $\left(22^{\circ} 26^{\prime} \mathrm{N}, 114^{\circ} 16^{\prime} \mathrm{E}\right)$. Individuals of $P$. viridis were held at $25^{\circ} \mathrm{C}$ and $30 \%$ salinity in a closed seawater system at The Swire Institute of
Marine Science (Cape d'Aguilar, Hong Kong). Seawater was changed every two days and mussels were fed twice a day with Isochrysis galbana $\left(\sim 100,000\right.$ cell $\left.\mathrm{mL}^{-1}\right)$ prior to experimentation.

\subsection{Eco-physiological parameters}

\subsubsection{Arrhenius temperature}

To obtain a set of temperatures to integrate into the DEB covariation method (Lika et al., 2011a,b), we estimated the Arrhenius temperature through mussel heart rate which has been shown to be a suitable proxy for measuring stress in Perna viridis in response to environmental changes (Nicholson, 2002; Nicholson and Lam, 2005; Ma, 2013). Mussels of different sizes were selected (shell length $2-2.99 \mathrm{~cm}$, $3-3.99 \mathrm{~cm}, 4-4.99 \mathrm{~cm}$ and $5-5.99 \mathrm{~cm}$, representing the population size range usually cultivated), with five replicates for each size class. Heart rates (HRs) were measured at five temperatures (i.e., $15^{\circ} \mathrm{C}, 20^{\circ} \mathrm{C}, 25^{\circ} \mathrm{C}$, $30^{\circ} \mathrm{C}$ and $35^{\circ} \mathrm{C}$ ) within the temperature range that $P$. viridis experiences in its natural environment $(\Sigma n=4$ size classes $\times 5$ temperatures $\times 5$ replicates $=100$ ). To achieve the desired experimental temperatures, a ramping rate of $1^{\circ} \mathrm{C}$ change every $30 \mathrm{~min}$ from ambient temperature $\left(25^{\circ} \mathrm{C}\right)$ was used, following Luk (2014). Animals were held at each temperature for $24 \mathrm{~h}$ after which heart beats were recorded for $>5 \mathrm{~min}$ following Burnett et al. (2013) and heart rates (HRs, in Hertz, Hz) calculated from the captured traces. Within a species' tolerance range, changes in HRs with temperature were illustrated by Arrhenius plots (i.e., $\ln (\mathrm{HR})$ vs $1 /$ temperature (in Kelvin)) and Arrhenius temperature $\left(T_{\mathrm{A}}\right)$ was calculated from the slope of the linear regression from the plots (Kooijman, 2010). The lower and upper tolerance temperatures were $15^{\circ} \mathrm{C}$ and $35^{\circ} \mathrm{C}$ which covered the lowest and highest temperature that $P$. viridis experiences in the natural environment (Tolo Harbour, data from 2013, Environmental Protection Department, HKSAR Government). The lower $\left(T_{\mathrm{AL}}\right)$ and upper $\left(T_{\mathrm{AH}}\right)$ boundaries of the Arrhenius temperature were obtained from the slope of the linear equation from the Arrhenius plots using natural-log HR data measured at optimal temperature and lower and upper tolerance temperatures respectively.

Slopes of linear equations (i.e. $T_{\mathrm{A}}, \mathrm{T}_{\mathrm{AL}}$ and $\mathrm{T}_{\mathrm{AH}}$ ) derived from Arrhenius plots of Perna viridis of different size classes were compared using Analysis of Covariance (ANCOVA, Zar, 1999). If the slopes were not significant, $T_{\mathrm{A}}, \mathrm{T}_{\mathrm{AL}}$ and $\mathrm{T}_{\mathrm{AH}}$ obtained from different size classes were pooled.

\subsubsection{Shape coefficient}

Body volume and surface area play crucial roles in DEB energetic exchanges and fluxes and can be described using the shape coefficient, an abstract quantity that allows conversion of the organism's shell length to surface area and structural volume. To estimate this parameter, we collected mussels with spent gonads (to minimize the effects of reproductive tissues on estimations of the shape coefficient). Shell length was measured $( \pm 0.1 \mathrm{~mm}$ ) and then animals dissected, blotted dry and tissue wet weights (without shells) measured ( $\pm 0.001 \mathrm{~g}$ ) to estimate the structural volume $(n=465)$. Tissue wet weight was most strongly related to shell length of Perna viridis (regression coefficient $=2.6$; coefficient of determination, $\mathrm{r}^{2}=0.943$ ) and the resultant shape coefficient was, therefore, derived using these two variables.

\subsubsection{Ingestion and assimilation rates}

To estimate food acquisition rates of Perna viridis collected mussels (shell length $4-5 \mathrm{~cm}$ ) were held in well-aerated and filtered $(0.7 \mu \mathrm{m}$; Whatman GF/F) seawater at $25^{\circ} \mathrm{C}$. A monoculture of the alga, Isochrysis galbana was added into beakers with predetermined volumes to achieve seven chlorophyll $a$ concentrations (i.e., 1.27, 1.90, 4.70, 5.97, 11.57, 19.07 and $28.10 \mu \mathrm{g} \mathrm{L}^{-1}$ ) to represent variation in food availability based on Hong Kong environmental conditions where $P$. viridis is intensively cultivated (Cheng, 2016) in order to calculate the mussel's surface area-specific maximum ingestion $\left(\left\{\dot{J}_{\mathrm{Xm}}\right\}\right)$ and assimilation rates ( $\left\{\dot{p}_{\mathrm{Am}}\right\}$ (see Sarà et al., 2013). Seven replicates of the seven 
concentrations were established together with four controls (i.e., beakers without animals) $\left(\sum n=7\right.$ concentrations $\times(7$ replicates +4 controls) $=77$ ). During experiments, the algal cells were mixed using magnetic stirrers and $20 \mathrm{~mL}$ algal solutions were sampled at the beginning of the experiment and at 30-minute intervals over $2 \mathrm{~h}$. The density of algal cells at each time was determined from counts using a haemocytometer. Mussels were then left for at least $18 \mathrm{~h}$ in $500 \mathrm{~mL}$ seawater without algae for defecation. The remaining algal food and faeces of each individual were collected under vacuum filtration $(0.7 \mu \mathrm{m}$; Whatman GF/F), dried and combusted to obtain dry weight (DW) and ash free dry weight (AFDW) values for the determination of assimilation efficiency (AE) as described by Conover (1966). Algae from control replicates were also collected, dried and combusted to determine particulate organic matter of each algal concentration. To obtain the energy conversion factor $\left(\mathrm{J} \mathrm{mg}^{-1}\right)$ of the algal food, the energy of $40 \mathrm{mg}$ algal pellets concentrated from the algal stock were measured using an oxygen bomb calorimeter (6765, Parr Instrument Company).

\subsubsection{Estimation of energy for somatic maintenance, growth and reserve density}

Perna viridis (shell length 4-4.5 cm) were fed with a monoculture of Isochrysis galbana over two weeks prior to experimentation. Subsequently the mussels were evenly distributed into eight tanks $(25 \times 25 \times 25 \mathrm{~cm})$ and held in a closed aquarium system using filtered $(0.22 \mu \mathrm{m})$ and aerated seawater maintained at $24 \pm 0.5^{\circ} \mathrm{C}$ and fed for two weeks. The tanks were then allocated to two treatments: either starved or well-fed (control) with four replicates for each group. Mussels were randomly selected every week to measure oxygen consumption (Pyroscience, FireStingO $\mathrm{O}_{2}$, Germany) in respiratory chambers. After measurement, the tissue dry weight (TDW) and AFDW of each individual were recorded. Measurements were taken until the decrease in TDW of starved individuals leveled off prior to a second decrease in TDW (see Sarà et al., 2013), and the volume-specific maintenance cost ( $\left.\left[\dot{p}_{\mathrm{M}}\right]\right)$ was determined from the corresponding oxygen consumption rates. The somatic mass index, which reflects the amount of energy investment in the soma, was also derived from the TDW and AFDW of starved and control animals for determination of energy for growth $\left(\left[E_{\mathrm{G}}\right]\right)$ and reserve density $\left(\left[E_{\mathrm{m}}\right]\right)$ following methods described in Cardoso (2007).

Derivation of DEB parameters from data obtained from the experimental procedures described above, and how the DEB model generates the output of LH traits, are discussed in Kearney (2012), Montalto et al. (2014) and Sarà et al. (2013).

\subsubsection{Derivation of DEB parameters for Perna viridis using the covariation method}

Experimental values, together with zero- and uni-variate data, such as lengths at birth and puberty, age-specific size and the relationship between tissue wet weight and size, obtained from the literature and other field measurements (see Table 1; Cheng, 2016) were introduced into the DEB covariation procedure (a set of Matlab routines available online at http://www.bio.vu.nl/thb/deb/deblab/add_my_pet/entries_ web/Perna_viridis/Perna_viridis_res.html) to estimate the DEB parameters (Table 2) which cannot be derived empirically (Lika et al., 2011a,b). The estimation procedure ensures that the species parameter values fall within a biologically realistic range. The covariation procedure also gives a 'goodness of fit' value (defined as $10 \times(1-$ mean relative error)) and completeness metric (described in Lika et al., 2011a,b; Matzelle et al., 2014) to evaluate the reliability of the DEB parameters obtained from the procedure.

2.3. Model simulation: performance of Perna viridis under anthropogenic stressors and possible impact on aquaculture

To increase realism in the DEB simulations and to provide useful information to address management options for Perna viridis
Table 1

Observed and predicted values of the dataset from DEB parameter estimation procedures for Perna viridis (for the observed value*: 1 = field observation, 2 = Laxmilatha et al., 2011; 3 = Tan, 1975; 4 = Rajagopal et al., 2006; 5 = Appukuttan, 1977; 6 = McFarland, 2015).

\begin{tabular}{llllll}
\hline Parameter & Unit & Definition & Observed* & Predicted & \\
\hline$a_{\mathrm{b}}$ & $\mathrm{d}$ & Age at birth & 0.83 & 0.727 & 2 \\
$a_{\mathrm{j}}$ & $\mathrm{d}$ & Age at metamorphosis & 12 & 11.96 & 3 \\
$a_{\mathrm{p}}$ & $\mathrm{d}$ & Age at puberty & 60 & 81.07 & 4 \\
$a_{\mathrm{m}}$ & $\mathrm{d}$ & Life span & 1825 & 1828 & 1 \\
$L_{\mathrm{b}}$ & $\mathrm{cm}$ & Physical length at birth & 0.007 & 0.006 & 2,4 \\
$L_{\mathrm{j}}$ & $\mathrm{cm}$ & Physical length at & 0.04 & 0.04029 & 2 \\
& & metamorphosis & & \\
$L_{\mathrm{p}}$ & $\mathrm{cm}$ & Physical length at puberty & 1.5 & 1.605 & 4 \\
$L_{\mathrm{i}}$ & $\mathrm{cm}$ & Ultimate physical length & 23 & 15.18 & 5 \\
$W_{\mathrm{p}}$ & $\mathrm{g}$ & Wet weight at sexual & 0.1 & 0.1 & 1 \\
& & maturity & & \\
$W_{\mathrm{i}}$ & $\mathrm{g}$ & Ultimate wet weight & 84.2 & 84.43 & 5 \\
$R_{\mathrm{i}}$ & $\# \mathrm{~d}^{-1}$ & Maximum reproduction & $1.59 \times 10^{5}$ & $1.589 \times 10^{5}$ & 6 \\
& & rate & & \\
\hline & & & &
\end{tabular}

Table 2

DEB primary parameters for Perna viridis after estimation procedure for model simulation.

\begin{tabular}{|c|c|c|c|}
\hline Parameter & Unit & Definition & Value \\
\hline$T_{\text {ref }}$ & $\mathrm{K}$ & Reference temperature & 298 \\
\hline$T_{\mathrm{A}}$ & $\mathrm{K}$ & Arrhenius temperature & 7,805 \\
\hline$T_{\mathrm{L}}$ & $\mathrm{K}$ & Lower tolerance temperature & 288 \\
\hline$T_{\mathrm{H}}$ & $\mathrm{K}$ & Upper tolerance temperature & 308 \\
\hline$T_{\mathrm{AL}}$ & $\mathrm{K}$ & Lower boundary of Arrhenius temperature & 8,215 \\
\hline$T_{\mathrm{AH}}$ & $\mathrm{K}$ & Upper boundary of Arrhenius temperature & 17,280 \\
\hline$\delta_{\mathrm{M}}$ & - & Shape coefficient & 0.1912 \\
\hline $\mathrm{AE}$ & - & Assimilation efficiency & 0.94 \\
\hline$\left\{\dot{J}_{X m}\right\}$ & $\mathrm{J} \mathrm{cm}^{-2} \mathrm{~d}^{-1}$ & Surface area-specific maximum ingestion rate & 182.7 \\
\hline$\left\{\dot{p}_{A m}\right\}$ & $\mathrm{J} \mathrm{cm}^{-2} \mathrm{~d}^{-1}$ & $\begin{array}{l}\text { Surface area-specific maximum assimilation } \\
\text { rate }\end{array}$ & 171.74 \\
\hline$\left[\dot{p}_{M}\right]$ & $\mathrm{J} \mathrm{cm}^{-3} \mathrm{~d}^{-1}$ & Volume-specific maintenance cost & 20.85 \\
\hline$\left[E_{G}\right]$ & $\mathrm{J} \mathrm{cm}^{-3}$ & Volume-specific cost for growth & 2603 \\
\hline$\left[E_{\mathrm{m}}\right]$ & $\mathrm{J} \mathrm{cm}^{-3}$ & Maximum reserve density & 7052 \\
\hline$\kappa$ & - & $\begin{array}{l}\text { Fraction of energy for somatic maintenance } \\
\text { and growth }\end{array}$ & 0.44 \\
\hline$\kappa_{\mathrm{R}}$ & - & Reproductive efficiency & 0.95 \\
\hline
\end{tabular}

aquaculture, we formulated different scenarios of local pollution effects and trophic enrichment, as these are major threats in Hong Kong waters and in Southeast Asia (reviewed by Williams et al., 2016). To achieve this, we generated scenarios by varying the $\left[\dot{p}_{M}\right]$ parameter and the functional response to study the potential differential effects due to both pollution and altered local trophic status on LH traits and harvesting time (time for mussels to reach commercial size, i.e., $5 \mathrm{~cm}$; Vakily, 1989) of $P$. viridis. Pollutant stressors such as heavy metals have been recorded to elicit additional metabolic costs in bivalves increasing maintenance costs by $20 \%$ (Cherkasov et al., 2006) and we, therefore, varied the $\left[\dot{p}_{M}\right]$ value from $5 \%$ to $20 \%$ following a scheme already used by Carrington et al. (2015) to represent the potential effects on LH traits exerted by pollutant stressors. We further varied the functional response ( $f$ ) from 0.2 to 0.85 to explicitly include the potential effects of varying food availability on mussel performance (note that when $f=1$ food is unlimited, when $f=0$ food is not available) as described by Pouvreau et al. (2006). Following the approach by Sarà et al. (2012, 2013), simulations were run using hourly seawater temperatures obtained from the Hong Kong Observatory (HKO).

\section{Results}

\subsection{DEB model parameters}

There was no significant effect of size on Arrhenius temperature 
a)

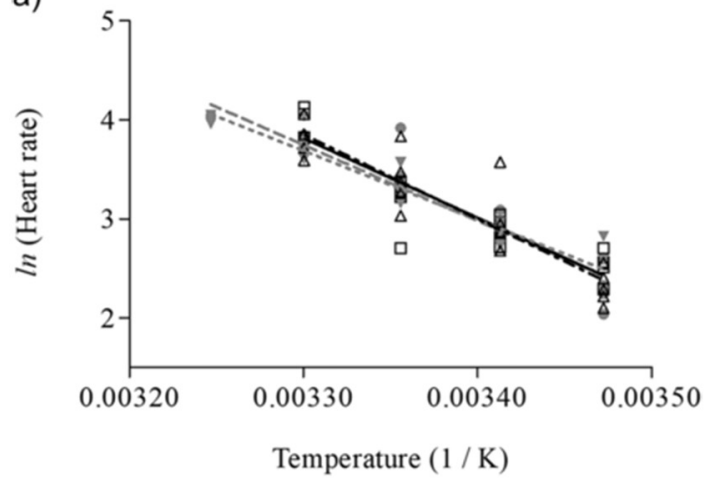

b)
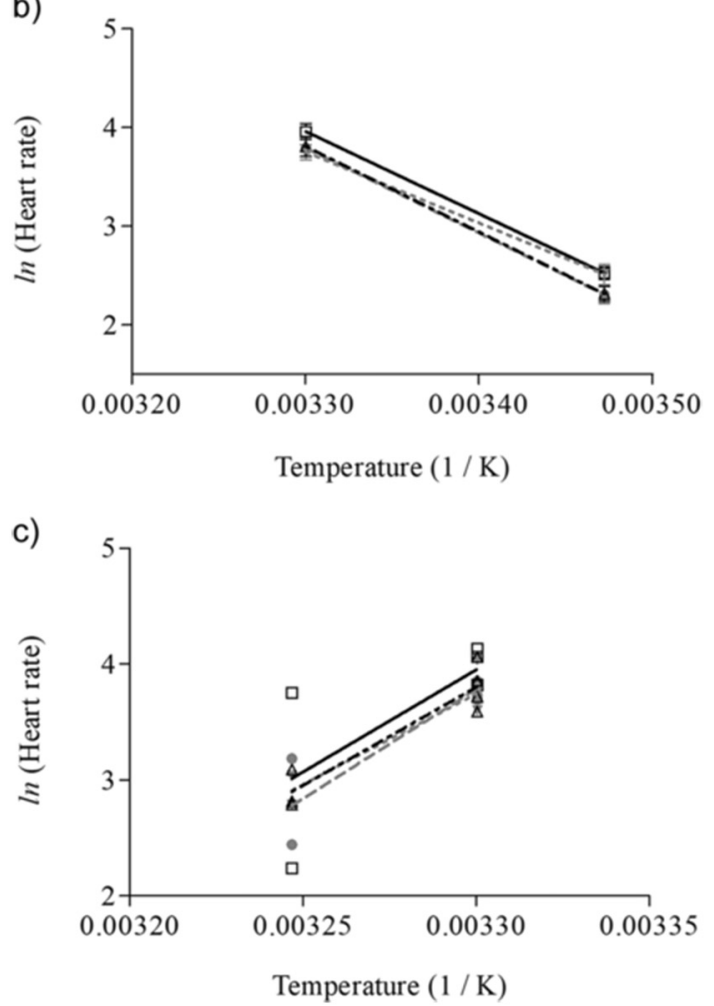

Fig. 1. Arrhenius plots showing variations in heart rates of Perna viridis of different size classes $2-2.99 \mathrm{~cm}$ ( with dash line), $3-3.99 \mathrm{~cm}$ ( $\square$ with solid line), 4-4.99 $\mathrm{cm}$ ( $\nabla$ with dotted line) and $5-5.99 \mathrm{~cm}$ ( $\Delta$ with dash-dotted line) over different experimental temperatures for the calculation of $\mathbf{a} T_{\mathrm{A}}, \mathbf{b} T_{\mathrm{AL}}$ (b) and $\mathbf{c} T_{\mathrm{AH}}$. There were no significant differences among sizes in $\mathrm{T}_{\mathrm{A}}, \mathrm{T}_{\mathrm{AL}}$ and $\mathrm{T}_{\mathrm{AH}}$.

(Fig. 1a; $\mathrm{F}_{3,71}=0.88, p>0.05$ ) and, as a consequence, size classes were pooled. $T_{\mathrm{AL}}$ (Fig. 1b; $\mathrm{F}_{3,30}=0.07, p>0.05$ ) and $T_{\mathrm{AH}}$ (Fig. 1c; $\mathrm{F}_{3,19}=0.07, p>0.05$ ), similarly, did not differ between size classes and were also pooled, giving $T_{\mathrm{L}}$ and $T_{\mathrm{H}}$ of $288 \mathrm{~K}$ (i.e., $15^{\circ} \mathrm{C}$ ) and $308 \mathrm{~K}$ (i.e., $35^{\circ} \mathrm{C}$ ) respectively. The experimental shape coefficient was 0.2795 while experimental AE was $0.94 \pm 0.08$ (mean $\pm \mathrm{SD}$ ), $\left\{\dot{J}_{\mathrm{Xm}}\right\}$, and $\quad\left\{\dot{p}_{\mathrm{Am}}\right\} \quad$ were $\quad 174.87 \pm 73.04 \mathrm{~J} \mathrm{~cm}^{-2} \mathrm{~d}^{-1} \quad$ and $166.24 \pm 74.44 \mathrm{~J} \mathrm{~cm}^{-2} \mathrm{~d}^{-1}$ respectively. The dry weight of starved individuals leveled off between weeks 12-14 (Fig. 2). The experimental mean $\left[\dot{p}_{\mathrm{M}}\right]$ of starved mussels during week 12-14 was $1.17 \pm 0.38 \mathrm{~J} \mathrm{~cm}^{-3} \mathrm{~h}^{-1}$ and the somatic mass indices (SMI) of fed and starved mussels were $1.80 \pm 0.38$ and $0.71 \pm 0.20 \mathrm{mg} \mathrm{cm}^{-3}$, respectively. All these empirically parameters were entered into the Matlab routine for estimation procedures (data summarized in Table 2). The DEB model for $P$. viridis had a goodness of fitness of 8.9 and completeness of 2.6 resulting in good overall performance, as it generated a good fit between observed and predicted data: for example,

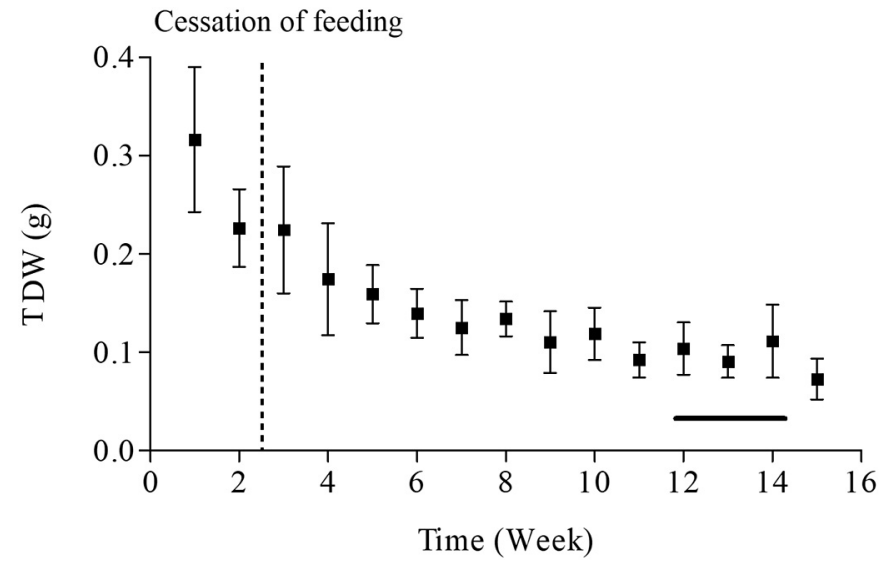

Fig. 2. Change (mean \pm SD) in tissue dry weight (TDW) of Perna viridis which leveled off from week 12-14 (underlined), indicating the complete depletion of the energy reserve of $P$. viridis at this time.
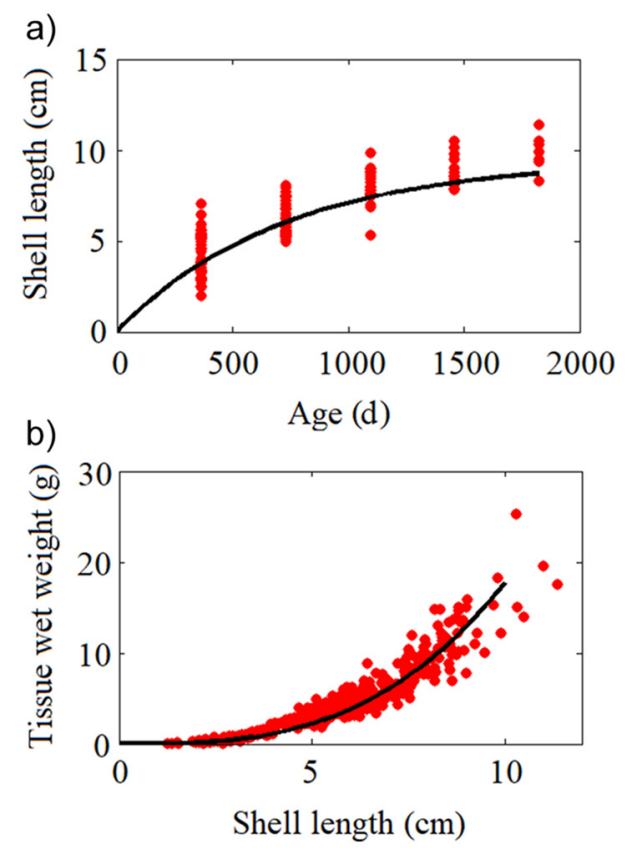

Fig. 3. Predicted (black lines) and observed (red dots) data in (a) shell length and age relationship and (b) tissue wet weight shell length relationship. Data from shell length age relationship and tissue wet weight shell length relationship were obtained from direct examination of mussel shell growth rings (Cheng, 2016) and from the shape coefficient measurements respectively. (For interpretation of the references to colour in this figure legend, the reader is referred to the web version of this article.)

length at birth and length at puberty were accurately predicted by the model (Table 1) as well as the growth curve and the relationship between tissue wet weight and shell length, which closely fitted the observed data (Fig. 3). The input data and model are available online (http://www.bio.vu.nl/thb/deb/deblab/add_my_pet/entries_web/ Perna_viridis/Perna_viridis_res.html).

\subsection{DEB model simulations}

Eighty-four spatially-contextualized models were run, crossing six levels of maintenance costs and 14 levels of food conditions (Fig. 4a, b). Our scenario analysis demonstrated that the increased basal metabolic demand negatively affected the LH outcomes by diminishing the reproductive output and growth of $P$. viridis at almost all levels of food 

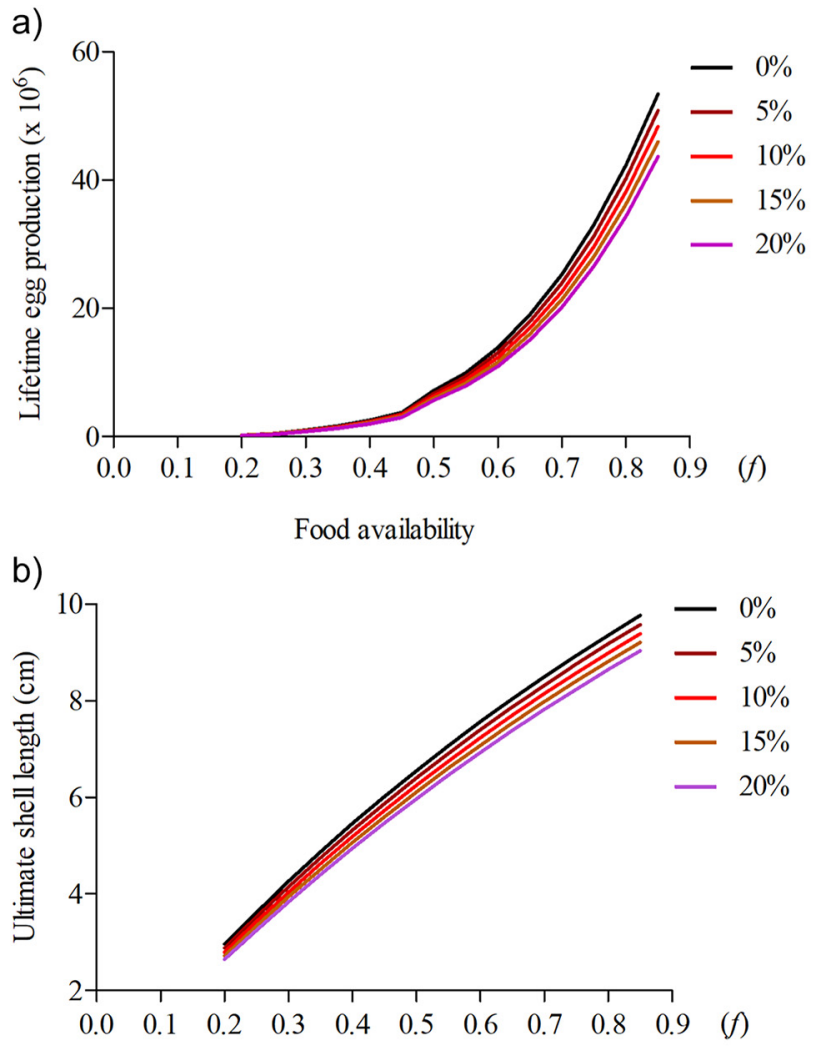

$\begin{array}{lllllllllll}0 & 0.12 & 0.28 & 0.47 & 0.73 & 1.10 & 1.65 & 2.57 & 4.40 & 9.90 & \left(\mu \mathrm{g} \mathrm{Chl} a \mathrm{~L}^{-1}\right)\end{array}$

Food availability

Fig. 4. Output of dynamic energy budget (DEB) model for Perna viridis illustrating the effects of increase in energy cost for basal maintenance on (a) lifetime egg production and (b) ultimate shell length. Holling type II functional response $(f$; Holling, 1959) was used to describe food availability. $f=\mathrm{X} /$ $\left(\mathrm{X}+\mathrm{X}_{\mathrm{K}}\right)$ where $\mathrm{X}$ is the environmental food density $\left(\mu \mathrm{g} \mathrm{Chl} a \mathrm{~L}^{-1}\right)$ and $\mathrm{X}_{\mathrm{K}}$ is the half-saturation coefficient (1.1 $\mu \mathrm{g} \mathrm{chl} a \mathrm{~L}^{-1}$; McFarland, 2015). The maintenance cost $\left(\left[\dot{p}_{M}\right]\right.$ with present day value $\left.20.85 \mathrm{~J} \mathrm{~cm}^{-3} \mathrm{~d}^{-1}\right)$ varied between $5 \%$ and $20 \%$. (For interpretation of the references to colour in this figure legend, the reader is referred to the web version of this article.)

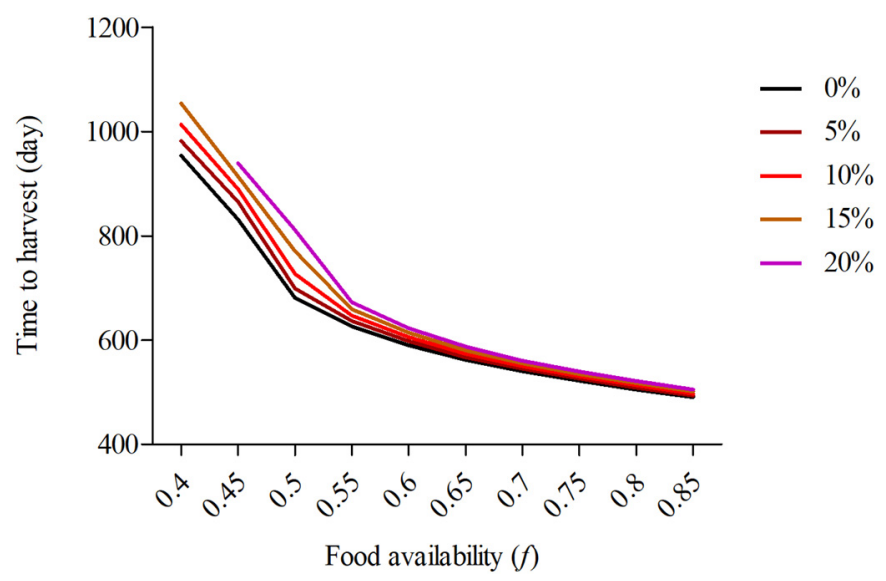

Fig. 5. Output of dynamic energy budget (DEB) model for Perna viridis illustrating the effects of increase in energy cost for basal maintenance on time to harvest (i.e., time when $P$. viridis reaches $5 \mathrm{~cm}$ in shell length). Holling type II functional response ( $f$; Holling, 1959) was used to describe food availability. $f=\mathrm{X} /\left(\mathrm{X}+\mathrm{X}_{\mathrm{K}}\right)$ where $\mathrm{X}$ is the environmental food density and $\mathrm{X}_{\mathrm{K}}$ is the halfsaturation coefficient $\left(1.1 \mu \mathrm{g}\right.$ chl $a \mathrm{~L}^{-1}$; McFarland, 2015). The maintenance cost $\left(\left[\dot{p}_{M}\right]\right.$ with present day value $20.85 \mathrm{~J} \mathrm{~cm}^{-3} \mathrm{~d}^{-1}$ ) varied between $5 \%$ and $20 \%$. density (Fig. 4a, b). When food density was low (represented by a low value (0.3) of $f$, which corresponds to $0.47 \mu \mathrm{g}$ chl $a \mathrm{~L}^{-1}$ ), $P$. viridis did not have sufficient energy for reproduction regardless of maintenance costs, and when food density increased, lifetime egg production was negatively related to maintenance costs (Fig. 4a). Even though $P$. viridis received sufficient food supply (i.e., $f=0.85$, chl $a=6.23 \mu \mathrm{g} \mathrm{L}^{-1}$ ), a $20 \%$ increase in energy investment for basal maintenance also reduced lifetime egg production by $18 \%$. The ultimate shell length was also dependent on both food density and increase in maintenance cost, with $7.5 \%$ reduction in growth at high food density (i.e., $f=0.85$ ) as a result of the $20 \%$ increase in maintenance costs. Increasing maintenance costs also extended the time needed for mussels to achieve commercial size (Fig. 5). Increasing food availability, however, mitigated the effects of the increase in maintenance cost on harvesting time, with the time to reach commercial size increasing by $13 \%$ and $3 \%$ under lower (i.e., $f=0.4$ ) and higher food availability (i.e., $f=0.85$ ) respectively (Fig. 5). When $f<0.4$ (i.e., chl $a=0.73 \mu \mathrm{L} \mathrm{L}^{-1}$ ), $P$. viridis could not, however, reach commercial size throughout its lifespan under various trophic conditions.

\section{Discussion}

\subsection{Energy allocation strategy of Perna viridis}

The parameter set derived through this study can be considered reliable for predictions (Lika et al., 2011b; Matzelle et al., 2014) due to the high goodness of fit and completeness expressed by the model (see Section 3.2) and manifested by the close fit between predicted model outputs and observed data. The only anomaly was between observed and predicted age at puberty (Table 1 ) which may be due to the simulated relatively slower, with respect to field conditions, growth rate of Perna viridis. Although there was a difference between predicted and observed ultimate physical length, the observed value is variable according to environmental conditions and the largest size encountered in the field sampling was $\sim 11 \mathrm{~cm}$ (Cheng, pers. obs.) which falls within the predicted value. Given such a close match between observed and predicted values, there is a high degree of confidence that the energy allocation strategy of $P$. viridis is reliably depicted from the DEB model.

Using the covariation method, maintenance cost and kappa $(\kappa)$, the vital parameters governing the energy for LH traits such as growth and reproduction (Kooijman, 2010; Burton et al., 2011), were estimated. Maintenance cost $\left(\left[\dot{p}_{\mathrm{M}}\right]\right)$ plays an important role in governing the ability of organisms to cope with varying environmental conditions and their persistence over time under various biotic (such as varying food availability) and abiotic (such as changes in salinity) conditions (Sarà, 2007; Sarà and De Pirro, 2011). The maintenance cost of Perna viridis was estimated to be $20.85 \mathrm{~J} \mathrm{~d}^{-1} \mathrm{~cm}^{-3}$, which is higher than other recorded mytilids (e.g., Mytilus californianus, $15.15 \mathrm{~J} \mathrm{~d}^{-1} \mathrm{~cm}^{-3}$; Matzelle et al., 2014 and Brachidontes pharaonis, $14 \mathrm{~J} \mathrm{~d}^{-1} \mathrm{~cm}^{-3}$; Montalto et al., 2014). A higher maintenance cost reflects higher basal metabolic demands of organisms for survival (see Sokolova and Lannig, 2008). The DEB model also revealed that $P$. viridis allocates more reserve energy for maturity maintenance and reproduction $(56 \%, 1-\kappa)$ than somatic maintenance and growth $(44 \%, \kappa)$. The energy investment in reproduction for $P$. viridis is much greater than recorded in other mytilids species such as Mytilus californianus (1.1\%; Matzelle et al., 2014) and Brachidontes pharaonis (1.7\%; Montalto et al., 2014), which agrees with the observed high Gonadosomatic Index $(\sim 30 \%)$ of $P$. viridis measured by Cheung (1993) in Hong Kong and further supports the accuracy of the DEB model.

\subsection{Chlorophyll a as a food proxy for model simulations}

There are various kinds of food sources in open coastal waters such as detritus and phytoplankton which could form part of a bivalve's diet. The combination of different food sources into the DEB model has, 
however, proved difficult as current formulations of the model can only take into account one food proxy (Rosland et al., 2009; Duarte et al., 2012). As a result, a single proxy for food, phytoplankton (expressed as chlorophyll $a, \operatorname{chl} a$ ), was chosen for the model simulation. Chlorophyll $a$ has previously been shown to be a reliable quantifier for derivation of DEB ecophysiological parameters for shellfish (Pouvreau et al., 2006) as well as for a variety of bioenergetic studies which have accurately simulated organismal responses under fluctuating conditions (e.g. Widdows and Staff, 2006; Ren and Schiel, 2008; Sarà et al., 2008; Ezgeta-Balić et al., 2011). Using chl $a$ as a proxy for the bivalves food source also has the added advantage of being able to run DEB models with chl $a$ data from remote sensing satellite imagery, which can allow predictions at larger scales (Sarà et al., 2011, 2012, 2013; Thomas et al., 2011). Such data can also be used to address aquaculture management solutions such as site-selection and monitoring of aquaculture operations as satellite chl $a$ data is now an open resource on many web sites (see Sarà et al., 2012, 2018).

\subsection{Potential effects of pollution on energy balance}

Since basal metabolic demand has priority over other physiological processes, any change of basal metabolism will impact important LH traits such as growth and reproduction (Kooijman, 2010). Understanding how maintenance cost varies can, therefore, be beneficial for studying the effects of environmental changes on species' fitness (Burton et al., 2011). Environmental pollutants such as heavy metals, for example, have been shown to increase the standard metabolic rate (i.e., rate reflecting the energy demand for basal maintenance) of various species (Baghdiguian and Riva, 1985; Lannig et al., 2006; Ivanina et al., 2008; Sokolova and Lannig, 2008). The scenarios employed in this study demonstrated the effects of increasing maintenance cost of Perna viridis due to varying environmental conditions which affected its LH traits, with a reduction in reproductive output and growth. Energy balance is, therefore, vital for stress tolerance, which involves trade-offs between maintenance costs and fitness-related traits (Sokolova et al., 2012). The negative energetic constraints due to increased basal maintenance costs can, however, be buffered with increasing food density (Carrington et al., 2015) which permits higher energy supply to fulfill basal metabolic needs without sacrificing contributions to other LH traits.

\subsection{Implication of model outputs for aquaculture management}

Under varying environmental conditions, mussels can alter the balance of their bioenergetic budgets, and the outcomes of such energetic decisions are important for managing shellfish culture (Rinaldi et al., 2014; Montalto et al., 2017). To evaluate the success of shellfish cultivation, one can assess the growth of the target species (Pogoda et al., 2011). The DEB model simulations for Perna viridis can, therefore, provide primary information on how environmentally induced increased basal maintenance costs may affect the growth rates and reproductive output of the mussel which will govern the ultimate harvesting time (Rinaldi et al., 2014). Traditionally, mussels are harvested when they reach the minimum commercial size (i.e., $5 \mathrm{~cm}$ for $P$. viridis; Vakily, 1989). With reduced growth, mussels take longer time to reach such commercial size, therefore, extending the harvesting time. Such extension in harvesting time subsequently increases operational costs of a mussel farm which can contribute up to $43 \%$ of total operating cost (Kripa and Mohamed, 2008). Prolonged cultivation also increases the risk of loss in biomass due to higher chances of exposure to environmental disturbances such as storms, phytotoxins, hypoxia and sudden salinity changes (Spencer, 2002; Sarà et al., 2018). Increases in operational cost and risk of losses, therefore, make such mussel aquaculture operations less profitable, which may reflect poor decisions in site selection (Spencer, 2002).

Indeed, the main objective of modern management strategies such as ecosystem based management is to provide tailored management measures based on ecological functioning principles at a sufficient scale to reduce impacts on economic yield. The DEB model can quantify species' LH traits as function of potential temporal fluctuations in local environmental variables (Sarà et al., 2012). Such an approach, therefore, makes the model extremely useful for prediction of time for the mussel to reach commercial size and subsequently estimating the operational cost for a selected site (Sarà et al., 2018). Our model shows that Perna viridis exerts extra energy to overcome additional energetic costs due to environmental fluctuations. Such energetic constraint diminishes the species' growth rate, one of the most important traits for an aquaculture facility which, as a consequence, extends cultivation time prior to harvesting. Another important trait for aquaculture practitioners is reproductive potential. Since the gametes contribute $30 \%$ of the total weight of $P$. viridis (Cheung, 1993), the amount of gametes can have a significant impact on the price of harvested mussels. Both traits, therefore, will affect the overall economic success of aquaculture facilities. Since traditional aquaculture farming practices usually results in higher primary productivity around aquaculture facilities (Dalsgaard and Krause-Jensen, 2006), and adequate food supply is able to alleviate the effects of energetic constraints caused by environmental stress and shorten harvesting time, this implies the possibility of integrated multi-trophic aquaculture involving the utilization of waste nutrients produced from higher trophic level organisms (e.g., fishes) for lower trophic levels (e.g., filter feeders, Sarà et al., 2012; Troell et al., 2009), an area in which the DEB model has been successfully applied. Such approaches, however, have yet to be applied to $P$. viridis, which may be a novel direction for better management of this aquaculture species.

\section{Conclusions}

With growing human populations in the past decades, aquaculture is becoming increasingly important to meet the increasing demand for seafood. Such practice, however, requires strategic management as aquaculture is vulnerable to deterioration in environmental quality which ultimately affects success of an aquaculture system and this is especially true in Southeast Asia. The present experimental and modelling approach paves the way towards understanding the energy allocation strategy of the important aquaculture species, Perna viridis, and can be used to illustrate the effects of changing environmental conditions on the species LH traits throughout its life span. Using this approach, the effects of various stressors on the target species can be explicitly revealed through changes in DEB parameter values which affect species' LH traits. With such flexibility, the DEB model becomes increasingly important for predicting species performance under varying environments, providing important information for the management and the increasing competitiveness of aquaculture to meet future demands.

\section{Acknowledgements}

MCFC and ALST were supported by HKU postgraduate studentships. This work was supported by Hong Kong Government RGC GRF Grant 780913 to GAW. Ms. Cecily Law, Charles Chui, Tak Chi Tsoi, Gabriel Lee and Mavis Law were indispensable for their help in the field and in experiment maintenance.

\section{References}

Appukuttan, K.K., 1977. On the occurrence of the green mussel Perna viridis (Linnaeus) in Andaman Island. Indian J. Fish. 24, 244-247.

Baghdiguian, S., Riva, A., 1985. Metabolic modifications brought by the synergic action of cadmium and experimental starvation of clams Ruditapes decussatus. Mar. Environ. Res. 17, 289.

Béjaoui-Omri, A., Béjaoui, B., Harzallah, A., Aloui-Béjaoui, N., El Bour, M., Aleya, L., 2014. Dynamic energy budget model: a monitoring tool for growth and reproduction 
performance of Mytilus galloprovincialis in Bizerte lagoon (southwestern Mediterranean Sea). Environ. Sci. Poll. Res. 21, 13081-13094.

Burnett, N.P., Seabra, R., Pirro, D.M., Wethey, D.S., Woodin, S.A., Helmuth, B., Zippay, M.L., Sarà, G., Monaco, C., Lima, F.P., 2013. An improved noninvasive method for measuring heartbeat of intertidal animals. Limnol. Oceanogr. Methods 11, 91-100.

Burton, T., Killen, S.S., Armstrong, J.D., Metcalfe, N.B., 2011. What causes intraspecific variation in resting metabolic rate and what are its ecological consequences? Proc. R. Soc. Lond. B Biol. Sci. 278, 3465-3473.

Cardoso, J.F.M.F., 2007. Growth and Reproduction in Bivalves: An Energy Budget Approach. PhD thesis. University of Groningen, The Netherlands.

Carrington, E., Waite, J.H., Sarà, G., Seben, K.P., 2015. Mussels as a model system for integrative ecomechanics. Annu. Rev. Mar. Sci. 7, 443-469.

Casas, S., Bacher, C., 2006. Modelling trace metal ( $\mathrm{Hg}$ and $\mathrm{Pb}$ ) bioaccumulation in the Mediterranean mussel, Mytilus galloprovincialis, applied to environmental monitoring. J. Sea Res. 56, 168-181.

Chalermwat, K., Szuster, B.W., Flaherty, M., 2003. Shellfish aquaculture in Thailand. Aquacult. Econ. Manag. 7, 249-261.

Cheevaporn, V., Menasveta, P., 2003. Water pollution and habitat degradation in the Gulf of Thailand. Mar. Poll. Bull. 47, 43-51.

Cheng, C.F.M., 2016. The Influence of Temperature Acclimation and Food on the Physiology and Dynamic Energy Budget of Perna viridis. MPhil thesis. The University of Hong Kong, Hong Kong.

Cherkasov, A.S., Biswas, P.K., Ridings, D.M., Ringwood, A.H., Sokolova, I.M., 2006. Effects of acclimation temperature and cadmium exposure on cellular energy budgets in the marine mollusk Crassostrea virginica: linking cellular and mitochondrial responses. J. Exp. Biol. 209, 1274-1284.

Cheung, S.G., 1993. Population dynamics and energy budgets of green-lipped musse Perna viridis (Linnaeus) in a polluted harbour. J. Exp. Mar. Biol. Ecol. 168, 1-24.

Conover, R.J., 1966. Assimilation of organic matter by zooplankton. Limnol. Oceanogr $11,338-345$.

Dalsgaard, T., Krause-Jensen, D., 2006. Monitoring nutrient release from fish farms with macroalgal and phytoplankton bioassays. Aquaculture 256, 302-310.

Duarte, P., Fernández-Reiriz, M.J., Labarta, U., 2012. Modelling mussel growth in ecosystems with low suspended matter loads using a dynamic energy budget approach. J. Sea Res. 67, 44-57.

Ezgeta-Balić, D., Rinaldi, A., Peharda, M., Prusina, I., Montalto, V., Niceta, N., Sarà, G. 2011. An energy budget for the subtidal bivalve Modiolus barbatus (Mollusca) at different temperatures. Mar. Environ. Res. 71, 79-85.

FAO, 2015. Species Fact Sheets - Perna viridis (Linnaeus 1758). Food and Agriculture Organization of the United Nations, Rome. http://www.fao.org/fishery/species/ 2691/en.

FAO, 2016. The State of World Fisheries and Aquaculture: Contributing to Food Security and Nutrition for all. Food and Agriculture Organization of the United Nations, Rome.

Filgueira, R., Rosland, R., Grant, J., 2011. A comparison of scope for growth (SFG) and dynamic energy budget (DEB) models applied to the blue mussel (Mytilus edulis). J. Sea Res. 6, 403-410.

Gopalakrishnan, S., Vijayavel, K., 2009. Nutritional composition of three estuarine bivalve mussels, Perna viridis, Donax cuneatus and Meretrix meretrix. Int. J. Food Sci. Nutr. 60, 458-463.

Gunderson, A.R., Armstrong, E.J., Stillman, J.H., 2016. Multiple stressors in a changing world: the need for an improved perspective on physiological responses to the dynamic marine environment. Annu. Rev. Mar. Sci. 8, 357-378.

Gutiérrez, J.L., Clive, G., Strayer, D.L., Iribarne, O.O., 2003. Mollusks as ecosystem engineers: the role of shell production in aquatic habitats. Oikos 101, 79-90.

Handisyde, N.T., Ross, L.G., Badjeck, M.C., Allison, E.H., 2006. The Effects of Climate Change on World Aquaculture: A Global Perspective. Aquaculture and Fish Genetics Research Programme. Stirling Institute of Aquaculture, DFID, Stirling Final Technical Report.

Holling, C.S., 1959. The components of predation as revealed by a study of small-mammal predation of the European pine sawfly. Can. Entomol. 91, 293-320.

Howard, J., Babij, E., Griffis, R., Helmuth, B., Himes-Cornell, A., Niemier, P., ... Xue, Y., 2013. Oceans and marine resources in a changing climate. Oceanogr. Mar. Biol. 51, 71-192.

Hutchinson, G.E., 1957. The multivariate niche. Cold Spring Harb. Symp. Quant. Biol. 22, 415-427.

Islam, M.S., Tanaka, M., 2004. Impacts of pollution on coastal and marine ecosystems including coastal and marine fisheries and approach for management: a review and synthesis. Mar. Poll. Bull. 48, 624-649.

Ivanina, A.V., Cherkasov, A.S., Sokolova, I.M., 2008. Effects of cadmium on cellular protein and glutathione synthesis and expression of stress proteins in eastern oysters, Crassostrea virginica Gmelin. J. Exp. Biol. 211, 577-586.

Kearney, M., 2012. Metabolic theory, life history and the distribution of a terrestrial ectotherm. Funct. Ecol. 26, 167-179.

Kooijman, S.A.L.M., 2010. Dynamic Energy Budget Theory for Metabolic Organization. Cambridge University Press, Cambridge.

Kripa, V., Mohamed, K.S., 2008. Green mussel, Perna viridis, farming in Kerala, India technology diffusion process and socioeconomic impacts. J. World Aquacult. Soc. 39, 612-624.

Lannig, G., Flores, J.F., Sokolova, I.M., 2006. Temperature dependent stress response in oysters, Crassostrea virginica: pollution reduces temperature tolerance in oysters. Aquat. Toxicol. 79, 278-287.

Laxmilatha, P., Rao, G.S., Patnaik, P., Rao, T.N., Rao, M.P., Dash, B., 2011. Potential for the hatchery production of spat of the green mussel Perna viridis Linnaeus (1758). Aquaculture 312, 88-94.

Lika, K., Kearney, M.R., Freitas, V., Van der Veer, H., Van der Meer, J., Wijsman, J.W.M., Pecquerie, L., Kooijman, S.A.L.M., 2011a. The "covariation method" for estimating the parameters of the standard dynamic energy budget model I: philosophy and approach. J. Sea Res. 66, 270-277.

Lika, K., Kearney, M.R., Kooijman, S.A.L.M., 2011b. The "covariation method" for estimating the parameters of the standard dynamic energy budget model II: properties and preliminary patterns. J. Sea Res. 66, 278-288.

Longdill, P.C., Healy, T.R., Black, K.P., 2008. An integrated GIS approach for sustainable aquaculture management area site selection. Ocean Coast. Manage. 51, 612-624.

Luk, I.M., 2014. The Ecophysiology and Dynamic Energy Budget of Septifer virgatus. MPhil thesis. The University of Hong Kong, Hong Kong.

Ma, W.L., 2013. The Role of Stress Tolerance on Marine Invasive Mussels. MPhil thesis. The University of Hong Kong, Hong Kong.

Mangano, M.C., Sarà, G., 2017. Collating science-based evidence to inform public opinion on the environmental effects of marine drilling platforms in the Mediterranean Sea. J. Environ. Manag. 188, 195-202.

Martinez, M., Mangano, M.C., Maricchiolo, G., Genovese, L., Mazzola, A., Sarà, G., 2018. Measuring the effects of temperature rise on Mediterranean shellfish aquaculture. Ecol. Indic. 88, 71-78.

Matzelle, A., Montalto, V., Sarà, G., Zippay, M., Helmuth, B., 2014. Dynamic energy budget model parameter estimation for the bivalve Mytilus californianus: application of the covariation method. J. Sea Res. 94, 105-110.

McFarland, K., 2015. Application of the dynamic energy budget theory to Perna viridis to model growth and reproduction under various environmental conditions. In: Dynamic Energy Budget Symposium, Marseille.

Montalto, V., Palmeri, V., Rinaldi, A., Kooijman, S.A.L.M., Sarà, G., 2014. Dynamic energy budget parameterisation of Brachidontes pharaonis, a Lessepsian bivalve in the Mediterranean Sea. J. Sea Res. 94, 47-51.

Montalto, V., Martinez, M., Rinaldi, A., Sarà, G., Mirto, S., 2017. The effect of the quality of diet on the functional response of Mytilus galloprovincialis (Lamarck, 1819): implications for integrated multitrophic aquaculture (IMTA) and marine spatial planning. Aquaculture 468, 371-377.

Nicholson, S., 2002. Ecophysiological aspects of cardiac activity in the subtropical mussel Perna viridis (L.) (Bivalvia: Mytilidae). J. Exp. Mar. Biol. Ecol. 267, 207-222.

Nicholson, S., Lam, P.K.S., 2005. Pollution monitoring in Southeast Asia using biomarkers in the mytilid mussel Perna viridis (Mytilidae: Bivalvia). Environ. Int. 31, 121-132.

Nisbet, R.M., Muller, E.B., Lika, K., Kooijman, S.A.L.M., 2000. From molecules to ecosystems through dynamic energy budget models. J. Anim. Ecol. 69, 913-926.

Petes, L.E., Menge, B.A., Murphy, G.D., 2007. Environmental stress decreases survival, growth, and reproduction in New Zealand mussels. J. Exp. Mar. Biol. Ecol. 351, 830-891.

Petes, L.E., Menge, B.A., Harris, A.L., 2008. Intertidal mussels exhibit energetic trade-offs between reproduction and stress resistance. Ecol. Monogr. 78, 387-402.

Pogoda, B., Buck, B.H., Hagen, W., 2011. Growth performance and condition of oysters (Crassostrea gigas and Ostrea edulis) farmed in an offshore environment (North Sea, Germany). Aquaculture 319, 484-492.

Pouvreau, S., Bourles, Y., Lefebvre, S., Gangnery, A., Alunno-Bruscia, M., 2006. Application of a dynamic energy budget model to the Pacific oyster, Crassostrea gigas, reared under various environmental conditions. J. Sea Res. 56, 156-167.

Rajagopal, S., Venugopalan, V.P., Van der Velde, G., Jenner, H.A., 2006. Greening of the coasts: a review of the Perna viridis success story. Aquat. Ecol. 40, 273-297.

Ren, J.S., Schiel, D.R., 2008. A dynamic energy budget model: parameterisation and application to the Pacific oyster Crassostrea gigas in New Zealand waters. J. Exp. Mar. Biol. Ecol. 361, 42-48.

Rinaldi, A., Montalto, V., Manganaro, A., Mazzola, A., Mirto, S., Sanfilippo, M., Sarà, G., 2014. Predictive mechanistic bioenergetics to model habitat suitability of shellfish culture in coastal lakes. Estuar. Coastal Shelf Sci. 144, 89-98.

Rosland, R., Strand, Ø., Alunno-Bruscia, M., Bacher, C., Strohmeier, T., 2009. Applying dynamic energy budget (DEB) theory to simulate growth and bio-energetics of blue mussels under low seston conditions. J. Sea Res. 62, 49-61.

Sarà, G., 2007. Sedimentary and POM: mixed sources for Cerastoderma glaucum in a Mediterranean shallow pond. Aquat. Living Resour. 20, 271-277.

Sarà, G., De Pirro, M., 2011. Heart beat rate adaptations to varying salinity of two intertidal Mediterranean bivalves: the invasive Brachidontes pharaonis and the native Mytilaster minimus. Ital. J. Zool. 78, 193-197.

Sarà, G., Romano, C., Widdows, J., Staff, F.J, 2008. Effect of salinity and temperature on feeding physiology and scope for growth of an invasive species (Brachidontes pharaonis-MOLLUSCA: BIVALVIA) within the Mediterranean Sea. J. Exp. Mar. Biol. Ecol. 363, 130-136.

Sarà, G., Martire, M.L., Sanfilippo, M., Pulicanò, G., Cortese, G., Mazzola, A., Manganaro, A., Pusceddu, A., 2011. Impacts of marine aquaculture at large spatial scales: evidences from $\mathrm{N}$ and $\mathrm{P}$ catchment loading and phytoplankton biomass. Mar. Environ. Res. 71, 317-324.

Sarà, G., Reid, G.K., Rinaldi, A., Palmeri, V., Troell, M., Kooijman, S.A.L.M., 2012. Growth and reproductive simulation of candidate shellfish species at fish cages in the Southern Mediterranean: Dynamic Energy Budget (DEB) modelling for integrated multi-trophic aquaculture. Aquaculture 324, 256-266.

Sarà, G., Palmeri, V., Montalto, V., Rinaldi, A., Widdows, J., 2013. Parameterisation of bivalve functional traits for mechanistic eco-physiological dynamic energy budget (DEB) models. Mar. Ecol. Progr. Ser. 480, 90-117.

Sarà, G., Mangano, M.C., Johnson, M., Mazzola, A., 2018. Integrating multiple stressors in aquaculture to build the blue growth in a changing sea. Hydrobiologia 809, 5-17.

Siah, A., Pellerin, J., Amiard, J.C., Pelletier, E., Viglino, L., 2003. Delayed gametogenesis and progesterone levels in soft-shell clams (Mya arenaria) in relation to in situ contamination to organotins and heavy metals in the St. Lawrence River (Canada). Comp. Biochem. Physiol. C Toxicol Pharmacol 135, 145-156.

Sidall, S.E., 1980. A clarification of the genus Perna (Mytilidae). Bull. Mar. Sci. 30, $858-870$. 
Smolders, R., Baillieul, M., Blust, R., 2005. Relationship between the energy status of Daphnia magna and its sensitivity to environmental stress. Aquat. Toxicol. 73, 155-170.

Sokolova, I.M., 2013. Energy-limited tolerance to stress as conceptual framework to integrate the effects of multiple stressors. Integr. Comp. Biol. 53, 597-608.

Sokolova, I.M., Lannig, G., 2008. Interactive effects of metal pollution and temperature on metabolism in aquatic ectotherms: implications of global climate change. Clim. Res. 37, 181-201.

Sokolova, I.M., Frederich, M., Bagwe, R., Lannig, G., Sukhotin, A.A., 2012. Energy homeostasis as an integrative tool for assessing limits of environmental stress tolerance in aquatic invertebrates. Mar. Environ. Res. 79, 1-15.

Spencer, B.E., 2002. Molluscan Shellfish Farming. Blackwell Science, Oxford.

Tan, W.H., 1975. Egg and larval development in the green mussel, Mytilus viridis Linnaeus. Veliger 18, 151-155.

Thomas, Y., Mazurié, J., Alunno-Bruscia, M., Bacher, C., Bouget, J.F., Gohin, F., Pouvreau, S., Struski, C., 2011. Modelling spatio-temporal variability of Mytilus edulis (L.) growth by forcing a dynamic energy budget model with satellite-derived environmental data. J. Sea Res. 66, 308-317.

Todgham, A.E., Stillman, J.H., 2013. Physiological responses to shifts in multiple environmental stressors: relevance in a changing world. Integr. Comp. Biol. 53, 539-544.

Troell, M., Joyce, A., Chopin, T., Neori, A., Buschmann, A.H., Fang, J.G., 2009. Ecological engineering in aquaculture-potential for integrated multi-trophic aquaculture (IMTA) in marine offshore systems. Aquaculture 297, 1-9.

Vakily, J.M., 1989. The Biology and Culture of Mussels of the Genus Perna. International Center for Living Aquatic Resources Management, Manila.

Van der Meer, J., 2006. An introduction to dynamic energy budget (DEB) models with special emphasis on parameter estimation. J. Sea Res. 56, 85-102.

Widdows, J., Staff, F., 2006. Biological effects of contaminants: measurement of scope for growth in mussels. ICES Tech. Mar. Environ. Sci. 40, 1-30.

Williams, G.A., Helmuth, B.S., Russell, B.D., Dong, Y.W., Thiyagarajan, V., Seuront, L., 2016. Meeting the climate change challenge: pressing issues in southern China and SE Asian coastal ecosystems. Reg. Stud. Mar. Sci. 8, 373-381.

Zar, J.H., 1999. Biostatistical Analysis, 4th. Prentice Hall, Upper Saddle River, NJ. 